\title{
Penerapan Pembelajaran Kooperatif Tipe Jigsaw Pada Materi Sistem Pencernaan Manusia Untuk Meningkatkan Hasil Belajar Siswa Kelas VIII SMP Negeri 4 Montasik Aceh Besar
}

\author{
Cut Nasriyati \\ Kepala Sekolah VIII SMP Negeri 4 Montasik Aceh Besar \\ Email.cutnasriyati@yahoo.co.id
}

\begin{abstract}
Abstrak
Penelitian ini bertujuan untuk mengetahui pembelajaran kooperatif tipe Jigsaw dapat meningkatkan hasil prestasi belajar siswa materi sistem pencernaan manusia pada kelas VIII SMP Negeri 4 Montasik Aceh Besar. Subjek penelitian adalah siswa kelas VIII berjumlah 16 orang siswa. Jenis penelitian ini adalah Penelitian Tindakan Kelas (PTK) yang dilakukan sebanyak dua siklus. Instrumen penelitian menggunakan teknik observasi, dokumentasi, tes dan non tes. Pengumpulan instrumen diperoleh dari kondisi awal, hasil penelitian yaitu Aktivitas guru pada siklus I memperoleh skor rata-rata $(2,90)$ termasuk ke dalam kategori cukup baik dan siklus II memperoleh skor rata-rata $(3,80)$ termasuk kedalam kategori baik. Aktivitas siswa pada siklus I memperoleh skor rata-rata $(2,60)$ termasuk kedalam kategori cukup baik dan siklus II memperoleh skor rata-rata $(3,70)$ termasuk kedalam kategori baik. Peningkatkan hasil belajar siswa pada siklus I nilai tes siswa diketahui yang tuntas berjumlah 11 siswa dengan persentase $(68,75 \%$.). Nilai tes pada siklus II memperoleh skor rata-rata $(76,25)$ dan termasuk kedalam kategori baik. Diketahui bahwa siswa yang memperoleh ketuntasan sebanyak 14 siswa dengan persentase ketuntasan belajar sebesar (87,5\%). Penerapan pembelajaran kooperatif tipe Jigsaw dapat meningkatkan hasil belajar dan aktivitas siswa pada materi sistem pencernaan manusia.
\end{abstract}

Kata Kunci : Hasil Belajar Siswa, Tipe Jigsaw, Sistem Pencernaan Manusia

\section{PENDAHULUAN}

Pertumbuhan dan perkembangan anak didik dalam proses pembelajaran dipengaruhi oleh faktor internal dan faktor eksternal. Salah satu faktor eksternal yang mempengaruhi proses pembelajaran adalah kemampuan guru dalam mengelola pembelajaran. Kegiatan pembelajaraan yang selama ini berlangsung di SMP Negeri 4 Montasik masih banyak menggunakan model pembelajaran yang konvensional, ditandai dengan: 1) berpusat pada guru, 2) penekanan pada menerima pengetahuan, 3)kurang berfariasi 4) kurang memberdayakan semua potensi siswa 5) menggunakan metode yang monoton.

Fakta dilapangan menunjukkan bahwa nilai hasil belajar siswa SMP Negeri 4 Montasik dengan menggunakan model pembelajaran konvensional pada materi sistem pencernaan manusia adalah rata-rata 60, belum memenuhi target KKM yang ditetapkan sekolah yaitu sebesar 75. Rendahnya hasil belajar siswa disebabkan olehkurangnya motivasi siswa, masih banyak siswa yang pasif, sebagian besar siswa tidak berani bertanya,aktifitas siswa dalam belajar dan diskusi masih rendah, dan kurangnya alat peraga atau fasilitas belajar, dan guru dominan sebagai pusat sumber pembelajaran.

Salah satu model pembelajaran yang berbeda dengan pembelajaran konvensional adalah pebelajaran kooperatif tipe Jigsaw Dengan menggunakan tipe Jigsaw diharapkan guru dapat menghasilkan siswa yang berprestasi, berjiwa gotong 
royong, dan bertanggung jawab pada tugasnya. Model pembelajaran ini merupakan model pembelajaran yang efektif dalam mengembangkan kemampuan siswa yang telah dimiliki terhadap materi yang diajarkan (Arends 1997).

Penelitian Tindakan Kelas (PTK) diperlukan untuk mengatasi permasalahan dalam proses pembelajaran sehingga dapat meningkatkan prestasi siswa. Guru sebagai pengajar diharapkan dapat mengembangkan potensi yang ada pada siswa, sehingga siswa tidak hanya belajar dari gurunya saja tetapi juaga dengan dirinya sendiri dan teman-temannya. Guru sebagai fasilitator hanya membimbing siswa terhadap kemampuan yang dimilikinya agar apa yang dipelajariya tidak tergantung kepada gurunya saja. Berdasarkan permasalahan diatas, peneliti mencoba melakukan penelitian tindakan kelas yag berjudul "Penerapan Pembelajaran Kooperatif Tipe Jigsaw pada Materi Sistem Pencernaan Manusia untuk meningkatkan Hasil Belajar Siswa Kelas VIII SMP Negeri 4 Montasik Aceh Besar"

\section{METODOLOGI PENELITIAN}

\section{Pendekatan dan Jenis Penelitian}

Penelitian tindakan merupakan upaya menguji-cobakan ide-ide ke dalam praktik untuk memperbaiki atau mengubah sesuatu agar memperoleh dampak nyata dari situasi. Penelitian tindakan kelas biasanya terdiri dari satu atau beberapa siklus, tergantung permasalahan atau hambatan yang ditemukan selama penelitian. Masing-masing siklus melalui tahap perencanaan tindakan, pelaksanaan tindakan, observasi, dan refleksi (Susanto, 2008:70).

\section{Waktu Penelitian}

Penelitian ini telah dilaksanakan di kelas VIII SMP Negeri 4 Montasik Aceh Besar pada tanggal 4 s.d 25 November pada tahun 2013.

\section{Subjek Penelitian}

Dalam penelitian ini adalah seluruh siswa kelas VIII SMP Negeri 4 Montasik Aceh Besar, yang berjumlah 16 siswa dan terdiri dari 4 orang siswa laki-laki dan 12 orang siswa perempuan.

\section{Prosedur Penelitian}

Menurut Suharsimi Arikunto(2002), Penelitian ini dilaksanakan dalam 2 (dua) siklus. Masing-masing siklus memiliki 4 (empat) tahap kegiatan antara lain kegiatan perencanaan, pemberian tindakan, pengamatan (Observasi) dan refleksi yang membentuk siklus sampai penelitian tuntas dilakukan. Sehingga diperoleh data yang dapat dihasikan jawaban dari permasalahan penelitian.

\section{Teknik Analisis Data}

\section{Analisis Hasil Belajar Siswa}

Pembahasan dilakukan dengan menggunakan teknik analisa deskriptif yaitu proses pengumpulan, mengklasifikasikan dan menganalisis data untuk penafsiran sehingga diperoleh gambaran yang jelas mengenai pengaruh penggunaan media belajar terhadap ketuntasan belajar siswa. Untuk mengetahui peran penggunaan media belajar terhadap ketuntasan belajar maka digunakan rumus persentase menurut Sudjana (2002:312) adalah: 
$\mathrm{P}=\frac{\mathrm{f}}{\mathrm{N}} \times 100 \%$
Keterangan :

$\mathrm{P} \quad$ : Persentase

$\mathrm{F} \quad$ : Nilai frekwensi

$\mathrm{N} \quad$ : Jumlah nilai seluruhnya

100 : Nilai tetap

\section{Analisis Tingkat Ketuntasan Belajar}

$$
\mathrm{P}=\frac{\text { Jumlah siswa yang tuntas }}{\text { Jumlah seluruh siswa }} \times 100 \%
$$

Pelajaran Biologi akan tuntas apabila $75 \%$ jumlah siswa dari suatu kelas mendapat nilai minimal 75 (sesuai KKM yang diterapkan di kelas VIII SMP Negeri 4 Montasik Aceh Besar yaitu 275).

\section{HASIL DAN PEMBAHASAN}

Pembahasan dalam Bab ini mengenai hasil yang diperoleh selama kegiatan penelitian yang dilakukan di SMP Negeri 4 Montasik Aceh Besar tentang penerapan model pembelajaran kooperatif tipe jigsaw di Kelas kelas VIII SMP, diantaranya akan dipaparkan deskripsi hasil penelitian, pembahasan dan tinjauan terhadap pertanyaan penelitian yang telah dikemukakan pada bab sebelumnya. Masing-masing data tersebut akan disajikan sebagai berikut.

\section{Hasil Penelitian}

\section{Deskripsi Penelitian Siklus I}

Pada penelitian ini, hasil belajar siswa diperoleh melalui tes akhir belajar secara tertulis dan dikerjakan secara mandiri. Penilaian dilakukan pada akhir proses kegiatan pembelajaran secara keseluruhan. Ada beberapa tahapan yang dilaksanakan siklus pertama.

\section{a. Siklus I}

\section{Tahap Perencanaan}

Pada tahap perencanaan ini, adapun yang dipersipkan oleh peneliti sebelum melaksanakan penelitian adalah sebagai berikut:

a. Menyususn Rencana Pelaksanaan Pembelajaran (RPP) untuk siklus I tentang materi sistem pencernaan manusia.

b. Menyusun lembar LKS

c. Membuat lembar kemampuan guru mengelola pembelajaran

d. Membuat alat evaluasi untuk mengukur hasil sebelum dan setelah diterapkannya kooperatif tipe jigsaw.

\section{Pelaksanaan tindakan}

Pelaksanaan pembelajaranjigsaw pada siklus 1 pada kelas VIII SMP Negeri 4 Montasik Aceh Besar. Guru menjelaskan kepada siswa tentang model jigsaw yang digunakan pada saat pembelajaran berlangsung dan cara penilaian,

\section{Observasi}

Pada tahap ini dilaksanakan observasi terhadap kemampuan guru mengelola pembelajaran dan aktivitas belajar dengan penggunaan model jigsaw 
Observasi aktivitas siswa dalam mengelola pembelajarandilaksanakan observerselama kegiatan pembelajaran berlangsung. Observer pada penelitian ini adalah tim peneliti (Peneliti dan beberapa temannya). Aktivitas siswa diperoleh dari pengamatan yang dilakukan oleh observer. Aktivitas siswa pada siklusI dapat dilihat pada Tabel 1 berikut:

Tabel 1 Aktivitas Belajar Siswa pada siklus-1

\begin{tabular}{|c|c|c|c|}
\hline No & Aspek yang diamati & Skor RPP-1 & Kategori \\
\hline 1. & Siswa memperhatikan guru saat membuka pelajaran & 3 & Baik \\
\hline & $\begin{array}{l}\text { Siswa mendengarkan tujuan pembelajaran yang } \\
\text { disampaikan guru }\end{array}$ & 3 & Baik \\
\hline & Siswa mendengarkan dan memperhatikan penjelasan guru & 3 & Baik \\
\hline 4. & Siswa membaca materi yang diberikan guru & 3 & Baik \\
\hline 5. & Siswa mengerjakan materi yang diberikan oleh guru & 3 & Baik \\
\hline 6. & Siswa membagi kelompok & 3 & Baik \\
\hline 7. & Siswa melakukan kegiatan pembelajaran & 3 & Baik \\
\hline 8. & Siswa membacakan kedepan hasil dari kegiatan & 3 & Baik \\
\hline & Siswa membandingkan hasil kegiatan setiap kelompok & 2 & Sedang \\
\hline & $\begin{array}{l}\text { Siswa mendiskusikan hasil yang didapat dari kegiatan } \\
\text { dalam kelompoknya. }\end{array}$ & 2 & Sedang \\
\hline & $\begin{array}{l}\text { Siswa menuliskan data hasil kegiatan kelompok di kertas } \\
\text { HVS yang telah disediakan }\end{array}$ & 3 & Baik \\
\hline 12. & Siswa melakukan tanya jawab dengan guru & 2 & Sedang \\
\hline 13.8 & Siswa menarik kesimpulan dari hasil kegiatan kelompok & 2 & Sedang \\
\hline 14. & Siswa memperhatikan guru menutup pelajaran & 3 & Baik \\
\hline & & 2,60 & $\begin{array}{l}\text { Cukup } \\
\text { baik }\end{array}$ \\
\hline
\end{tabular}

Dari tabel diatas, dapat diketahui bahwa skor rata-rata aktivitas siswa dalam belajar 2,60 skor rata-rata tingkat kemampuan siswa pada siklus ini tergolong cukup baik karena skor rata-ratanya terletak antara 2,50 sampai 3,50, dimana jika 2,50 $\leq \mathrm{TKG}$ $<$ 3,50 maka tingkat kemampuan siswa beraktivitas mengikuti pembelajaran tergolong cukup baik (Nurjanah, 2006:22).

\section{Refleksi}

Berdasarkan hasil yang telah dikumpulkan pada tahap observasi dan analisis dapat diketahui bahwa kemampuan siswa dalam melakukan aktivitas belajar dan guru mengelola pembelajaran cukup baik. Hal ini menunjukkan bahwa siswa dalam melakukan aktivitas perlu ditingkatkan. Hal ini disebabkan siswa dan guru kurang berpartisipasi aktif dalam menerapkan model jigsaw dan siswa kurang memahaminya. Oleh karena itu untuk siklus II, peneliti akan lebih meningkatkan motivasi kepada siswa dalam berdiskusi dengan temannya dengan memberikan penghargaan kepada kelompok terbaik, terkompak dan terdisiplin.

\section{Siklus II}

\section{Tahap Perencanaan}

Berdasarkan hasil refleksi atau masukan pada KBM kedua, guru menyusun rencana pertemuan kedua. Dalam tahap perencanaan pada siklus kedua, yang harus dilakukan oleh guru adalah:

1) Menyusun rancana pembelajaran (RPP) untuk pertemuan kedua. 
2) Membuat instrumen yaitu alat untuk mengumpulkan data seperti lembar Pengamatan aktivitas siswa, membuat soal, dan angket respon siswa

3) Membuat lembar kerja Siswa (LKS)

\section{Tindakan}

Selanjutnya guru melanjutkan tindakan. Pelaksanaan tindakan kelas yaitu melaksanakan tindakan belajar mengajar sesuai dengan RPP pertemuan kedua bersamaan dengan kegiatan demonstrasi sesuai dengan tahapan jigsaw yang dilakukan siswa terhadap materi yang diajarkan guru. Materi yang akan diajarkan pada siklus 2 yaitu Sistem Pencernaan Manusia. Di akhir pembelajaran dilakukan tes.

\section{Tahap Observasi}

Proses observasi dilaksanakan pada saat penelitian tindakan berlangsung oleh pengamat dengan menggunakan lembar observasi yang telah dipersiapkan sebelumnya. Observasi dimaksudkan untuk mengetahui pelaksanaan pembelajaran Sains yang dilaksanakan siswa dan bagaimana aktivitas guru mengelola pembelajaran

Tabel 2 Aktivitas Belajar siswa RPP-2

\begin{tabular}{|c|c|c|c|}
\hline No & Aspek yang diamati & Skor RPP-3 & Kategori \\
\hline 1. & $\begin{array}{l}\text { Siswa memperhatikan guru saat membuka } \\
\text { pelajaran }\end{array}$ & 4 & $\begin{array}{c}\text { Sangat } \\
\text { baik }\end{array}$ \\
\hline 2. & $\begin{array}{l}\text { Siswa mendengarkan tujuan pembelajaran yang } \\
\text { disampaikan guru }\end{array}$ & 4 & $\begin{array}{c}\text { Sangat } \\
\text { baik }\end{array}$ \\
\hline 3. & $\begin{array}{l}\text { Siswa mendengarkan dan memperhatikan } \\
\text { penjelasan guru }\end{array}$ & 4 & $\begin{array}{c}\text { Sangat } \\
\text { baik }\end{array}$ \\
\hline 4. & $\begin{array}{l}\text { Siswa membaca materi yang telah diberikan } \\
\text { oleh guru }\end{array}$ & 4 & $\begin{array}{c}\text { Sangat } \\
\text { baik }\end{array}$ \\
\hline 5. & $\begin{array}{l}\text { Siswa mengerjakan materi yang diberikan oleh } \\
\text { guru }\end{array}$ & 4 & $\begin{array}{c}\text { Sangat } \\
\text { baik }\end{array}$ \\
\hline 6. & Siswa membagi kelompok & 4 & $\begin{array}{c}\text { Sangat } \\
\text { baik }\end{array}$ \\
\hline 7. & Siswa melakukan kegiatan pembelajaran & 4 & $\begin{array}{c}\text { Sangat } \\
\text { baik }\end{array}$ \\
\hline 8. & Siswa membacakan kedepan hasil dari kegiatan & 4 & $\begin{array}{c}\text { Sangat } \\
\text { baik }\end{array}$ \\
\hline 9. & $\begin{array}{l}\text { Siswa membandingkan hasil kegiatan setiap } \\
\text { kelompok }\end{array}$ & 4 & $\begin{array}{c}\text { Sangat } \\
\text { baik }\end{array}$ \\
\hline 10. & $\begin{array}{l}\text { Siswa mendiskusikan hasil yang didapat dari } \\
\text { kegiatan dalam kelompoknya. }\end{array}$ & 3 & Baik \\
\hline 11. & $\begin{array}{l}\text { Siswa menuliskan data hasil kegiatan kelompok } \\
\text { di kertas HVS yang telah disedikan }\end{array}$ & 3 & Baik \\
\hline 12. & Siswa melakukan tanya jawab dengan guru & 3 & Baik \\
\hline 13. & $\begin{array}{l}\text { Siswa menarik kesimpulan dari hasil kegiatan } \\
\text { kelompok }\end{array}$ & 3 & Baik \\
\hline 14. & Siswa memperhatikan guru menutup pelajaran & 4 & $\begin{array}{c}\text { Sangat } \\
\text { baik }\end{array}$ \\
\hline
\end{tabular}




\begin{tabular}{|r|c|c|}
\hline Jumlah & $\mathbf{3 , 7 0}$ & Baik \\
\hline
\end{tabular}

Berdasarkan tabel di atas, menunjukkan bahwa kemampuan siswa melakukan aktivitas belajar mengalami peningkatan dari siklus sebelumnya. Rata-rata aktivitas siswa mengikuti pelajaran siklus II ini adalah 3,70. Skor rata-rata aktivitas siswa pada siklus II ini tergolong baik karena skor rata-ratanya terletak antara 3,50 sampai 4,50 maka tingkat aktivitas siswa tergolong baik (Nurjanah, 2006:2).

a. Ketuntasan belajar siswa pada materi sistem pencernaan manusia

Tabel 3 Hasil Belajar Siswa siklus-II

\begin{tabular}{|c|c|c|c|c|}
\hline No & Nama Siswa & $\begin{array}{c}\text { Nilai } \\
\text { RPP-2 }\end{array}$ & $\begin{array}{c}\text { Tuntas(KKM) } \\
\mathbf{7 5}\end{array}$ & $\begin{array}{c}\text { Tidak } \\
\text { Tuntas }\end{array}$ \\
\hline 1 & Anisya Fira & 90 & Tuntas & - \\
\hline 2 & Arif Munandar & 70 & - & Tidak \\
\hline 3 & Ariska & 85 & Tuntas & - \\
\hline 4 & Fidel & 85 & Tuntas & - \\
\hline 5 & Khairul Nisa & 80 & Tuntas & - \\
\hline 6 & M. Syawal & 90 & Tuntas & - \\
\hline 7 & Miftahul Zannah & 90 & Tuntas & - \\
\hline 8 & Muajinah & 90 & Tuntas & - \\
\hline 9 & Muhammad Rauf & 90 & Tuntas & - \\
\hline 10 & Mujahiddin & 85 & Tuntas & - \\
\hline 11 & Rahmad & 85 & Tuntas & - \\
\hline 12 & Sutiawan & 90 & Tuntas & - \\
\hline 13 & Syafira & 70 & - & Tidak \\
\hline 14 & Umar & 90 & Tuntas & - \\
\hline 15 & Ummi Ajizah & 85 & Tuntas & - \\
\hline 16 & Wilda Yani & 85 & Tuntas & - \\
\hline & JUMLAH & 1360 & & $87,5 \%$ \\
\hline & Rata-Rata & 85 & $12,5 \%$ \\
\hline
\end{tabular}

Berdasarkan tabel diatas siswa yang tuntas 14 orang dan yang tidak tuntas 2 orang KKM yang ditetapkan Sekolah $75 \%$. Setelah melewati siklus penelitian pertama yang telah dilakukan oleh peneliti didapatkan hasil belajar dan aktivitas belajar siswa mengalami peningkatan yang signifikan. Dari tabel di atas dapat kita lihat bahwa hasil belajar siswa pada RPP-2 sebesar 87,5\%. Hasil belajar siswa meningkat sempurna setalah menggunakan model pembelajaran tipe jigsaw untuk hal ini dikarenakan siswa sudah paham dan mengerti tentang materi yang diajarkan dengan menggunakan model kooperatif tipe jigsaw.

Pada penelitian ini hasil belajar siswa dilihat dari hasil tes akhir yang diberikan setelah pembelajaran melalui model kooperatif tipe jigsaw. Tes berbentuk choice sebanyak 20 butir soal, hasil belajar yang diharapkan adalah siswa dapat menyelesaikan Materi sistem pencernaan manusia.Berdasarkan hasil analisis deskriptif diatas diperoleh 
bahwa, ketuntasan hasil belajar siswa secara klasikal berdasarkan kriteria yang sudah ditetapkan sudah tercapai. Dari hasil tes belajar (tes akhir) yang diperoleh menunjukkan hampir $100 \%$ siswa tuntas belajar, artinya dari 16 siswa hanya beberapa siswa yang tidak tuntas dalam mengikuti Pelajaran. Ketuntasan hasil belajar tersebut menunjukan bahwa penguasaan terhadap materi sistem pencernaan manusia sudah baik.

Dari hasil pengolahan data menunjukkan bahwa metode pembelajaran dengan menggunakan model pembelajaran kooperatif tipe jigsaw pada materi sistem pencernaan manusia dapat meningkatkan hasil belajar siswa. Karena mengajar menggunakan metode yang tepat akan turut menentukan hasil yang dicapai sesuai yang dikatakan oleh Mulyasa (2006:107) penggunaan metode yang tepat akan turut menentukan efektifitas dan efisiensi pembelajaran. Pembelajaran perlu dilakukan dengan sedikit ceramah dan metode-metode yang berpusat pada guru serta lebih menekankan pada interaksi peserta didik. Penggunaan metode yang bervariasi akan sangat membantu peserta didik dalam mencapai tujuan pembelajaran.

\section{Refleksi}

Berdasarkan hasil yang telah dikumpulkan pada tahap observasi dan analisis dapat diketahui bahwa kemampuan guru mengelola pembelajaran tergolong sangat baik. Hal ini menunjukkan bahwa ada peningkatan kemampuan guru dalam mengelola pembelajaran dan aktivitas siswa mengikuti pembelajaran serta hasil belajar siswa meningkat dibandingkan RPP I. Peningkatan hasil belajar siswa dari siklus pertama sampai siklus kedua terus mengalami peningkatan hampir semua siswa dinyatakan tuntas, oleh sebab itu penulis tidak melanjutkan kesiklus tiga.

\section{Data Hasil Angket Tanggapan Siswa terhadap model jigsaw}

Dari Hasil Angket yang dibagikan kepada siswa untuk mengetahui tanggapan siswa mengenai penerapan model pembelajaran kooperatif tipe jigsaw pada materi sistem pencernaan manusia kelas VIII SMP Negeri 4 Montasik Aceh Besar dapat dilihat pada tabel berikut:

Tabel 4 Nilai Respon Siswa dari data hasil Angket

\begin{tabular}{|l|l|c|c|}
\hline \multirow{2}{*}{ No } & \multicolumn{1}{|c|}{ Option } & \multicolumn{2}{c|}{$\begin{array}{c}\text { Responden Peserta } \\
\text { didik }\end{array}$} \\
\cline { 2 - 4 } & $\begin{array}{l}\text { Tanggapan } \\
\text { Positif }\end{array}$ & $\begin{array}{c}\text { Tanggapan } \\
\text { Negatif }\end{array}$ \\
\hline 1. & Apakah kamu senang dengan pelajaran Sains & $60 \%$ & $39,4 \%$ \\
\hline 2 & $\begin{array}{l}\text { Bagaimana pendapatmu mengikuti pelajaran } \\
\text { Sains pada materi sistem pencernaan manusia } \\
\text { yang disampaikan oleh gurumu }\end{array}$ & $75,8 \%$ & $24,2 \%$ \\
\hline 3 & $\begin{array}{l}\text { Apakah kamu dapat memahami dengan jelas } \\
\text { materi Sistem Pencernaan Manusia }\end{array}$ & $60 \%$ & $39,4 \%$ \\
\hline 4. & $\begin{array}{l}\text { Apakah kamu dapat memahami dengan jelas atau } \\
\text { tidak bahasa yang digunakan dalam LKS? }\end{array}$ & $69,7 \%$ & $30,3 \%$ \\
\hline 5 & $\begin{array}{l}\text { Apakah kamu merasa senang dengan tugas } \\
\text { menyusun langkah kerja pada LKS? }\end{array}$ & $72,7 \%$ & $27,3 \%$ \\
\hline 6 & $\begin{array}{l}\text { Apakah kamu senang mengikuti pembelajaran } \\
\text { dengan cara kelompok yang diajarkan pada } \\
\text { materi Sistem Pencernaan Manusiadibanding } \\
\text { dengan belajar kelompok lainnya? }\end{array}$ & $72,7 \%$ & $72,3 \%$ \\
\hline
\end{tabular}


ISSN : $2656-5781$

\begin{tabular}{|l|l|c|c|}
\hline 7 & $\begin{array}{l}\text { Apakah kamu merasa senang jika dapat } \\
\text { menemukan sendiri informasi yang baru }\end{array}$ & $81,8 \%$ & $18,2 \%$ \\
\hline 8 & $\begin{array}{l}\text { Apakah kamu merasa senang jika hasil dari } \\
\text { kegiatanmu dapat pujian dari guru }\end{array}$ & $78,8 \%$ & $21,2 \%$ \\
\hline 9 & $\begin{array}{l}\text { Apakah kamu senang belajar sains berkelompok } \\
\text { dalam mengerjakan suatu kegiatan }\end{array}$ & $60,6 \%$ & $39,4 \%$ \\
\hline 10 & $\begin{array}{l}\text { Apakah dalam penyelesaian permasalahan } \\
\text { tersebut terkait dengan materi yang pernah kamu } \\
\text { pelajari sebelumnya }\end{array}$ & $57,6 \%$ & $42,4 \%$ \\
\hline & Respon Positif & $\mathbf{6 9 , 0 \%}$ & $\mathbf{3 0 , 9 \%}$ \\
\hline & Respon Negatif & \\
\hline
\end{tabular}

Sumber: Data primer (diolah)

\section{Pembahasan}

\section{Aktivitas Siswa Mengikuti Pelajaran dengan Menggunakan Model Jigsaw}

Pengamatan aktivitas siswa selama pembelajaran berlangsung dilakukan dengan menggunakan lembar observasi kegiatan siswa. Hasil pengamatan aktivitas siswa selama pembelajaran berlangsung

Dari hasil aktivitas pertama dapat diketahui bahwa skor rata-rata aktivitas siswa dalam belajar 2,60 dikategorikan sangat baik karena siswa mampu mengikuti proses belajar mengajar dengan menggunakan model jigsaw

Dari hasil aktivitas kedua didapatkan aktivitas rata-rata 3,70\% lebih tinggi beberapa persen dari aktivitas pertama, pada pertemuan kedua siswa lebih termotivasi dalam mengikuti materi Sistem Pencernaan Manusia. Serta siswa mampu menguasai materi yang diajarkan oleh guru dengan menggunakan model pembelajaran tipe jigsaw di SMP Negeri 4 Montasik Aceh Besar.

\section{Aktivitas Guru mengelola Pembelajaran}

Penelitian ini dilaksanakan sebanyak 2 kali pertemuan. Pada penelitian ini peneliti terlibat langsung dalam mengajar pembelajaran dengan model pembelajaran kooperatif tipe jigsaw. Data yang diperoleh dari hasil pengamatan kemampuan guru dalam mengelola pembelajaran menunjukkan bahwa nilai rata-rata yang diperoleh guru setiap aspek yang diamati selama dua pertemuan berkisar antara 2 sampai 3. Nilai ini berada pada kriteria baik berdasarkan kriteri yang telah ditetapkan. Diantara beberapa kemampuan guru, ada beberapa aspek yang menonjol nilai rata-ratanya, diantaranya, kemampuan menjelaskan langkah-langkah kerja dalam kelompok, kemampuan mengoptimalkan interaksi siswa dalam bekerja, kemampuan memimpin diskusi, kemampuan siswa untuk mau bertanya, kemampuan mengajukan dan menjawab pertanyaan.

Pada siklus I kemampuan guru mengelola pembelajaran 2,90 skor rata-rata tingkat kemampuan guru pada siklus ini tergolong cukup baik hal ini karena guru menguasai sepenuhnya materi yang diajarkan serta model pembelajaran yang diberikan, ditambah lagi guru menguasai ruangan serta mampu menarik perhatian dan minat belajar siswa.

Pada siklus II rata-rata kemampuan guru mengelola pembelajaran siklus II ini adalah 3,80 tergolong baik pada siklus II guru bukan saja sudah mampu menarik perhatian siswa, bahkan guru sudah bisa menarik simpati siswa dan mengarahkan siswa 
dalam mengikuti proses belajar mengajar yang dilaksanakan dengan menggunakan model jigsaw.

\section{Ketuntasan Belajar Siswa}

Berdasarkan hasil pengamatan terhadap siswa selama pembelajaran yang dilakukan diketahui bahwa aktivitas siswa pada saat experiencing (mengalami) dan pada saat cooperating (bekerjasama) selama proses pembelajaran berlangsung adalah aktif. Siswa aktif karena senang, minat, dan termotivasi akan LKS dan penghargaan yang diberikan.

Muhibin (2005:73) Menyatakan bahwa motivasi belajar adalah keseluruhan daya penggerak dalam diri siswa menimbulkan kegiatan belajar yang menjamin kelangsungan belajar itu sehingga tujuan yang dikehendakai tercapai.Ini dapat dilihat pada lampiran aktivitas siswa selama tiga kali pertemuan.Sebelas aspek yang diamati dari siswa terlihat berada dalam batas toleransi waktu yang telah ditetapkan sesuai dengan tabel di atas. Sesuai dengan teori kontruktivisme, menurut Johar (2006:74) belajar merupakan kegiatan yang aktif dimana siswa membangun sendiri pengetahuannya dan mencari sendiri makna dari suatu yang mereka pelajari”.

Pada siklus I jumlah siswa yang tuntas ada 11 orang sedangkan yang tidak tuntas ada 5 orang sesuai dengan Kriteria Ketuntasan Minimal 75\%. Banyaknya siswa yang tidak tuntas karena siswa belum paham cara mengajar guru, dan belum menguasai materi dengan baik sehingga kepercayaan diri waktu mengajar berkurang dan membuat suasana belajar menjadi pasif.

Sedangkan pada siklus II siswa yang tuntas ada 14 orang sedangkan siswa yang tidak tuntas ada 2 orang pada siklus II siswa sudah paham dengan cara pembelajaran dan model yang telah diajarkan oleh guru, serta siswa sudah mengikuti pelajaran tentang materi sistem pencernaan manusia dengan menggunakan model jigsaw. Siswa antusias dalam bekerja kelompok dan mau bertanya tentang hal-hal yang tidak tau serta siswa juga mampu menjawab pertanyaan yang diajukan oleh taman lainnya.

\section{Respon siswa selama mengikuti pelajaran dengan menggunakan model jigsaw}

Angket respon siswa diberikan pada akhir pertemuan yaitu setelah siswa melakukan tes akhir. Angket respon siswa bertujuan untuk mengetahui perasaan siswa, minat siswa dan pendapat siswa mengenai pembelajaran dengan menggunakan model pembelajaran kooperatif tipe jigsaw. Respon siswa terhadap kegiatan pembelajaran berdasarkan hasil pengamatan menunjukkan lebih dari $70 \%$ siswa senang terhadap komponen pembelajaran dengan menggunakan model jigsaw pada materi sistem pencernaan manusia.

Dari tabel di atas dapat kita lihat bahwa siswa sangat tertarik mengikuti pelajaran sains pada materi sistem pencernaan dengan menggunakan metode kooperatif tipe jigsaw, terlihat jelas dari hasil angket yang disebarkan, yaitu terlihat pada tanggapan positif siswa $65,0 \%$. Tanggapan Negatif $30,9 \%$.

\section{Kesimpulan}

Berdasarkan hasil penelitian dan pembahasan yang dilakukan penulis pada siswa kelas VIII SMP Negeri 4 Montasik Aceh Besar dengan menggunakanpenerapan pembelajaran Kooperatif Tipe Jigsaw dapat meningkatkan hasil belajar siswa dalam Sistem Pencernaan Manusia, maka kesimpulan yang dapat ditarik yaitu aktivitas guru 
pada materi Sistem Pencernaan Manusia dengan menggunakan penerapan pembelajaran Kooperatif Tipe Jigsaw, pada siklus I memperoleh skor rata-rata sebesar $(2,90)$ dan termaksud kedalam kategori cuku baik, Pada siklus II memperoleh skor rata-rata sebesar $(3,80)$ dan termaksud kedalam kategori baik. Aktivitas siswa pada materi Sistem Pencernaan Manusia dengan menggunakan penerapan pembelajaran Kooperatif Tipe Jigsaw, pada siklus I memperoleh skor rata-rata sebesar $(2,60)$ dan termaksud kedalam kategori cuku baik, pada Siklus II memperoleh skor rata-rata sebesar $(3,70)$ dan termaksud kedalam kategori baik. Peningkatkan hasil belajar siswa dalam materi Sistem Pencernaan Manusia dengan menggunakan penerapan pembelajaran Kooperatif Tipe Jigsaw, pada Siklus I Nilai tes siswa diketahui bahwa 5 siswa yang tidak mencapai ketuntasan belajar dengan persentase $(31,25 \%)$ dan siswa yang tuntas berjumlah 11 siswa dengan persentase $(68,75 \%$.). Dengan nilai rata-rata $(75,43)$, nilai tes Pada Siklus II memperoleh skor rata-rata sebesar $(85,00)$ dan termaksud kedalam kategori baik. Dapat diketahui bahwa hanya 2 siswa yang tidak mencapai ketuntasan belajar yakni dengan persentase $(12,5 \%)$, dan siswa yang memperoleh ketuntasan sebanyak 14 siswa dengan persentase ketuntasana belajar sebesar $(87,5 \%)$.

\section{DAFTAR PUSTAKA}

Arikunto, Suharsimi, 2008, Penelitian Tindakan Kelas, Jakarta, Bumi Aksara.

Arends, R. 2008. Learning to Teach. Buku 2, Terjemahan. Belajar untuk mengajar. Terj. Soejipto HP dan Sujipto SM. Yogyakarta: Pustaka Belajar.

Eveyn CP. 2005. Anatomi dan Fisiologi untuk Paramedis. Cet ke-27. Jakarta: Gramedia.

Guyton AC. 2012. Fisiologi Manusia dan Mekanisme Kejadian Penyakit (Human Physiology and Mechanism of Disease). Terjemahan. Ed ke-3. Jakarta: Buku Kedokteran EGC.

Hamalik, 1980. Kurikulum dan Pembelajaran. Jakarta: Bumi Aksara.

Haryanto, 2004. Sistem Pencernaan. Jakarta: PT Paramita Buana Pustaka

Lie dalam Rusman, 2011, Model - Model Pembelajaran, Jakarta: PT Raja Grafindo Persada

Slavin Robert. Coorperatif Learning Theory research and Practise Buston Ally and Bacon PublisherSudjana dalam Kunandar, 2001, Penelitian Tindakan Kelas, Jakarta, Rajagrafindo Persada.

Suyitno, A. 2006. Pemilihan Model-model pembelajaran dan penerapannya di sekolah. Semarang: Universitas Negeri Semarang.

Slameto. 2003. Belajar dan Faktor - Faktor Yang Mempengaruhinya. Jakarta : Rineka cipta

Wahyuni S. 2006. Buku penuntunBiologi kelas xi jilid 2.Jakarta: Erlangga 